\title{
Effect of Adding Selenium-enriched Dried Algae to Ration on Productive and Reproductive Performance of Male Barki Sheep
}

\author{
H. Ghobashy', M. H. Ahmed², A. Gamal Al-Din', S. M. Zahran² \\ and H. S. Zewail ${ }^{2}$ \\ ${ }^{1}$ Animal Production Research Institute, Agriculture Research Centre, Cairo, Egypt. \\ ${ }^{2}$ Animal and Fish Production Department, Faculty of Agriculture (Saba Basha) Alex \\ University, Egypt.
}

Corresponding author: H. Ghobashy, e-mail: ghobashy2002@yahoo.com

\begin{abstract}
This study was set for more than one year to evualte the effects of dietary addition of selenium-enriched dried algae on productive and reproductive performances of Barki sheep. Twenty eight ram-lambs (aged 4-5 months) were randomly divided into four equal groups $(n=7)$. Basal concentrate mixture was prepared and supplemented with or without Sealgae (selenium enriched micro-algae Spirulina, Atrhrospira platensis). Four experimental concentrate mixtures were prepared, the control (basal concentrate mixture without any supplementation) (I) and the other three experimental concentrate mixtures (II, III and IV) were supplemented by Se- algae at levels of $0.2 ; 0.4$ and $0.6 \mathrm{mg} / \mathrm{kg} \mathrm{DM}$ of the diet, respectively. Animals of the four groups were randomly assigned to feed on one of these four concentrate mixtures. In addition of concentration mixture animals of all groups were fed ad libitum on berseem hay.Feed supplementation with Se-algae significantly increased animal's final live body weights and weight gains compared with control group. Significant increases in white blood cells counts were observed in animals fed diets supplemented with Se-algae when compared with the control group. Animals receiving concentrate mixture supplemented with Sealgae at $0.4 \mathrm{mg}$ recorded the highest $(P<0.05)$ value of packed cell volume when compared with the other two treatment groups. Dietary inclusion of different levels of Se-algae resulted in significant increases in blood total protein and albumin relative to the control group. The lowest value $(p<0.04)$ of plasma globulin was observed in group fed diet containing Se-algae at 0.6 $\mathrm{mg}$. Plasma urea nitrogen was significantly increased as a result of supplementing diets with 0.4 $\mathrm{mg}$ of Se-algae. However, Se-algae supplementation reduced plasma cholesterol $(p<0.046)$ and total lipid $(p<0.0001)$ contents as compared with the control group. The plasma aspartate aminotransferase (AST) and alkaline phosphatase (ALP) levels of ram-lambs were significantly affected by adding Se-algae to their diets. Significant increases in T-AOC, GSH-Px and SOD as Se-algae level increased. Conversely, plasma malondialdehyde (MDA) was significantly decreased in a dose-dependent manner. Sperm ejaculate volume, progressive motility, normal sperm, live sperm, total sperm output, total motile sperm and total functional sperm fraction (TFSF) were increased $(P \leq 0.05)$ in groups supplemented with Se-algae comparing with the control group. As opposed to the previous effect, sperm concentration, abnormal sperm and dead sperm significantly $(P \leq 0.05)$ decreased comparing with the control group. Seminal plasma total protein increased $(P<0.05)$ in the groups given 0.4 and $0.6 \mathrm{mg}$ Se-algae. Seminal plasma albumin increased $(P<0.05)$ in the group that received $0.4 \mathrm{mg}$ Se-algae diet as compared to the control group, while seminal plasma globulin was decreased $(P<0.05)$. Seminal plasma total lipids decreased $(\mathrm{P} \leq 0.02)$. Seminal plasma cholesterol and triglycerides were not significantly affected. Seminal plasma ALT and ALP significantly $(P \leq 0.01)$ decreased due to including Se-algae in ram-lambs diet as compared to the control group.In conclusion, addition of Se-algae to the diet of ram-lambs improved their growth performance, semen quality, antioxidant status and blood constituents during rearing periods.
\end{abstract}

Keywords: Sheep, Hematology, Serum constituents, Semen characteristics, Oxidative status

\section{INTRODUCTION}

Sheep production, as most agricultural enterprises, is affected by economic forces as well as environmental factors (Marai, 1987). Exposure to these factors causes a series of strong changes in the sheep biological 
functions that include depression in feed intake, efficiency and utilization, disturbances in metabolism of water, protein, energy, and mineral balances, enzymatic reactions, hormonal secretions and blood metabolites. Such changes end with low live body weight and impaired reproduction, i.e. depression in age at puberty, reproductive activity and fertility (Habeeb et al., 1992). In sheep, sexual behavior and semen quality are the main factors that limit male reproduction efficiency along the year (Aller et al., 2012). The efficiency of sperm production, libido and quality of sperm tend to remain uniform throughout the reproductive life of an animal but may be significantly altered by age, nutrition, environment, health status, drugs, and chemicals (Togun and Egbunike, 2006). Reproductive functions are highly demanding in both nutrients quality and quantity; in this way, nutritional status is a very important modulator of reproduction in sheep and goats (Blache et al., 2008).

Several studies have demonstrated interaction between nutrition and reproduction in sheep and goats. For example, flushing or minerals have been shown to improve production and reproduction parameters (Madibela et al., 2002; Griffiths et al., 2007). Selenium (Se) occurs in all cells and body tissues; its content in an organism varies according to the amount of the element in the feed ration (Kim and Mahan, 2001). The role of selenium as an antioxidant indicated importance for maintaining or improving semen quality in animals (Irvine, 1996). The increase in the formation of reaction oxygen species (ROS) was noted to decrease fertility, as the ROS will attack the membranes of the spermatozoa and decrease their viability (Irvine, 1996). Selenium increases the antioxidant glutathione peroxidase (GSH-Px) activity, which decreases the ROS and preserves semen quality and, subsequently, fertility in rams (Kendall et al., 2000). Moreover, organic Se is a highly available form of Se for livestock and provides antioxidant protection at a level greater than inorganic Se (Mahan, 1999; Mahmoud and Edens, 2003; Al-Waeli et al., 2013).

It is necessary to mention that Spirulina (Atrhrospira platensis) is a rich source of phycocyanin, as antioxidant biliprotein pigment and carotenoids (Cheong et al., 2010). However, scientific information available on performance and antioxidative status in Barki ram-lambs fed combinations of algae and Se are still limited.

In view of these facts, the present research was conducted on weaned ram-lambs to study the effect of dietary selenium-enriched micro-algae Spirulina (Atrhrospira platensis) supplementation on growth performance, blood biochemical constituents, semen characteristics and anti-oxidative status, under summer environmental condition of Egypt.

\section{MATERIALS AND METHODS Animals and housing}

This trial was carried out at the Experimental Station of Animal Production, Borg-El Arab, Alexandria Governorate, belonging to Animal Production Research Institute, Agricultural Research Center, Ministry of Agriculture, Egypt. Twenty eight Barki ram-lambs 4-5 months of age and weighing $26.83-27.67 \mathrm{~kg}$ were divided according to age and weight into four 
similar groups of six animals each and were housed in separate stalls. The experimental animals were kept under the same managerial and hygienic conditions. Before beginning the experiment animals were treated against internal and external parasites and intero-toximia.

\section{Source of selenium-enriched dried algae}

The selected cyanobacterium Spirulina platensis (Arthrospira platensis) were obtained from Agric. Microbiology Dept. National Research Centre (NRC), Giza, Egypt.

\section{Experimental diets}

Basal concentrate mixture consists of $37 \%$ crushed corn, $30 \%$ crushed barley, $20 \%$ wheat bran, $10 \%$ soybean meal, $2 \%$ lime stone and $1 \%$ salt. Basal concentrate mixture was supplemented with or without Se-algae (selenium enriched micro-algae Spirulina, Atrhrospira platensis). Four experimental concentrate mixtures were prepared, the control (basal concentrate mixture without any supplementation, I, and the other three experimental concentrate mixtures (II, III and IV) were supplemented by Se- algae at levels of 0.2, 0.4 and $0.6 \mathrm{mg} / \mathrm{kg} \mathrm{DM}$ of the diet, respectively. Animals of the four groups were randomly assigned to feed on one of these four concentrate mixtures. In addition to these concentrate mixtures animals of all groups were fed ad libitum on berseem hay.

Algae contain $1 \mathrm{mg} \mathrm{Se} / g$ algae; the control diet, thus contains only the endogenous Se contained in the ingredients of the diet. Control was the basal diet containing $0.08 \mathrm{mg} \mathrm{Se} / \mathrm{kg}$ diet. The four groups of lambs were randomly assigned to fed ad libitum on the four experimental diets in feeding experiment that lasted until sexual maturity. Animals were kept for two weeks prior to the start of the experiment for adaptation.

\section{Growth performance and body weight gain}

Lambs were individually weighed monthly in the morning before access to feed and water. Individual live weights of every treatment group were totaled and the average monthly weight gain was calculated by subtracting the average initial body weight of a certain period from the final average body weight of the same period.

\section{Blood collection and analyses}

Blood samples were collected monthly from the jugular vein of each lamb in the morning before access to feed and water. A part of blood samples were immediately withheld into heparinized tubes to analyze red blood cell (RBCs) counts and white blood cell (WBCs) counts according to Provan et al. (2004). Hemoglobin ( $\mathrm{Hb}$ ) and packed cell volume (PCV) were determined according to conventional methods (Hepler, 1966). Semen are obtained from coagulated blood samples centrifugation at $3000 \mathrm{rpm}$ for $20 \mathrm{~min}$, and serum were harvested and stored at $-20^{\circ} \mathrm{C}$ for later analyses. Serum total protein, albumin, glucose, urea- $\mathrm{N}$, creatinine, total cholesterol, total lipids, triglycerides, ALT, AST, ALP, MDA, T-AOC, SOD and GSH-Px enzymes activities, were 
assayed using chemical commercial kits of Diamond Diagnostics, Egypt. Globulin was estimated by subtraction of albumin from total protein.

\section{Sampling and semen traits}

Semen samples were collected weekly over 8 weeks using an artificial vagina and the samples of each week were subjected to chemical analysis. Semen collection and handling were carried out and evaluated according to the international guidelines (IRRG, 2005). Ejaculated volume was measured to the nearest $0.01 \mathrm{ml}$ immediately after collection, semen was maintained at $35^{\circ} \mathrm{C}$ in a water bath for evaluation. Fresh semen samples were used for measure went of sperm concentration by using the improved Neubauer hemocytometer slide method as described by Smith and Mayer (1955). Total sperm output (TSO) was calculated by multiplying semen ejaculate volume by semen concentration. Individual sperm motility was estimated at 400x magnification (Kamar, 1960). Assessment of live and abnormal spermatozoa was performed using an eosinnigrosin blue-staining mixture (Blom, 1950). The percentages of live, dead and abnormal spermatozoa were determined using stains that penetrated cells with damaged membranes. Normal live sperm exclude the eosin stain and appear white in color, whereas dead sperm take up eosin and appear pinkish in color because of loss of membrane integrity. Normal sperm have an oval head with a long tail. Abnormal sperm have head, midpiece or tail defects, such as a large or a misshapen head or a crooked or a double tail. The total number of motile sperm was calculated by multiplying the percentage of motile sperm by the total sperm outputs. The total functional sperm fraction (TFSF) was also calculated by multiplying the total sperm output and sperm motility and normal-morphology sperm (Correa and Zavos, 1996). Evaluation of seminal initial fructose was carried out immediately after collection according to Mann (1948).

Seminal plasma was separated by centrifugation at $3000 \mathrm{rpm}$ for 20 minutes and stored at $-20^{\circ} \mathrm{C}$ in Eppendorf tubes for further analysis of total protein and albumin. Globulin values were obtained by subtracting albumin values from corresponding values of total protein. Total lipids, triglycerides, cholesterol alkaline phosphatase, aspartate aminotransferase (AST), alanine aminotransferase (ALT), lipid peroxidation (Malondialdehyde) (MDA), total antioxidant capacity (TAC), superoxide dismutase (SOD) and glutathione peroxidase (GSH-Px) were determined in seminal plasma calorimetrically using commercial kits obtained from (Bio-Diagnostics, Egypt) according to the procedure outlined by the manufacturer.

\section{Statistical analysis}

Data of each growing and slaughter experiments were analyzed using general linear model (GLM) procedure (SAS, 2002). Duncan's Multiple Range Test (1955) was used to detect any variations between means.

\section{RESULTS AND DISCUSSION}

\section{Body weight and weight gain}

Data on the effect of dietary Se-algae supplementation on growth performance of Barki ram-lambs are presented in Table (1). The data indicated 
that Se-algae significantly increased their final body weight $(P<0.05)$ and total body weight gain at the end of the feeding experiment $(P<0.002)$ as compared to the control group. Dietary supplementation of Se-algae at $0.2,0.4$ and $0.6 \mathrm{mg}$ Se-algae/kg had positive effects on growth performance.These improvement agree with previous studies on the effects of selenium on the digestibility of nutrients. Naziroglu et al. (1997) reported that combined supplementation of Se and vitamin $E$ increased acetic, propionic, butyric and total volatile fatty acids concentration, and the total counts of protozoa of the ruminal fluid of lambs in vivo. Our results suggest that the good effectiveness of Se from Se-enriched alga can be explained by the high bioavailability of selenomethionine. Although inorganic selenite can be utilized for selenoprotein biosynthesis, only selenomethionine can be incorporated nonspecifically into body proteins in place of methionine (McConnell and Hoffman 1972), because tRNA Met does not discriminate between Met and Se-Met (Schrauzer, 2000). Mahan and Parrett (1996) reported that selenium retention in the organism is higher when Se-enriched yeast rather than sodium selenite is used as a dietary Se source. About $64 \%$ of consumed Se is excreted in case of sodium selenite while only $47 \%$ of $\mathrm{Se}$ is excreted when Se-enriched yeast is fed. Also, Se from Seenriched yeast does not have higher absorption from the gastrointestinal tract compared to sodium selenite. Therefore the high bioavailability of Se from Seenriched yeast is not caused by higher absorption.

Table (1). The effect of different levels of dietary Se-algae supplementation on the body weight and weight gain of Barki ram-lambs $(n=7)$

\begin{tabular}{|c|c|c|c|c|c|}
\hline \multirow{2}{*}{ Parameters } & \multicolumn{4}{|c|}{ Se-algae supplementation (mg/kg DM) } & \multirow{2}{*}{ P-value } \\
\hline & Control & 0.2 & 0.4 & 0.6 & \\
\hline Initial body weight (kg) & $24.98 \pm 1.65$ & $24.62 \pm 0.90$ & $23.65 \pm 1.26$ & $23.00 \pm 0.73$ & NS \\
\hline Final body weight (kg) & $40.31^{b} \pm 1.50$ & $46.58^{\mathrm{a}} \pm 6.16$ & $43.68^{\mathrm{ab}} \pm 0.81$ & $42.42^{\mathrm{ab}} \pm 1.25$ & 0.05 \\
\hline Body weight gain $(\mathrm{kg})$ & $15.33^{b} \pm 0.36$ & $21.70^{\mathrm{a}} \pm 1.28$ & $20.03^{\mathrm{a}} \pm 1.08$ & $19.42^{\mathrm{a}} \pm 1.20$ & 0.002 \\
\hline
\end{tabular}

\section{Blood hematology}

The effects of dietary Se-algae supplementation levels on blood hematological characteristics of ram-lambs are presented in Table (2). Jones and Allison (2007) reported that hematological values of sheep were $9-15 \times 10^{6}$ cells $/ \mu$ l for RBC's, 27-45\% for PCV and 9-15g/dl for Hb. Hemoglobin concentrations and red blood cell counts obtained from this study were between $(11.45$ and $11.62 \mathrm{~g} / \mathrm{dl})$ and $\left(10.94\right.$ and $\left.11.68 \times 10^{6} \mathrm{~mm}^{3}\right)$, respectively. The hemoglobin and red blood cells level of the control rams were similar to those of rams supplemented with Se-algae. However, dietary Se-algae supplementation caused a significant increase in white blood cell counts when compared with the control group. Rame-lambs supplemented with Se-algae at levels 0.4 and 0.6 $\mathrm{mg}$ recorded the highest $(\mathrm{P}<0.0001)$ values of white blood cell counts $(10.64$ and $10.47 \times 10^{3} / \mathrm{mm}^{3}$ respectively). These results agree with those reported by Ali et al. (2009) who found that after 3 months of treated Awassi rams with 175 $\mathrm{mg} / \mathrm{ram}$ vitamin $\mathrm{E}$ and $70 \mathrm{mg} / \mathrm{ram}$ vitamin $\mathrm{E}$ plus $2800 \mathrm{mg}$ selenium, the 
percentage of lymphocytes was increased compared with the untreated group. Leucocytes play an important role in non-specific or innate immunity and their count can be considered as an indicator of relatively lower disease susceptibility (Matanović et al., 2007).

\section{Table (2). The effect of different levels of dietary Se-algae supplementation on blood hematologic parameters of the experimental ram- lambs $(n=7)$}

\begin{tabular}{|c|c|c|c|c|c|}
\hline \multirow{2}{*}{ Parameters } & \multicolumn{4}{|c|}{ Se-algae supplementation (mg/kg DM) } & \multirow{2}{*}{ P- value } \\
\hline & Control & 0.2 & 0.4 & 0.6 & \\
\hline $\mathrm{Hb}(\mathrm{g} / \mathrm{dl})$ & $11.62 \pm 0.11$ & $11.59 \pm 0.25$ & $11.58 \pm 0.15$ & $11.45 \pm 0.48$ & NS \\
\hline $\mathrm{RBC}_{\mathrm{s}}\left(\times 10^{6} / \mathrm{mm}^{3}\right)$ & $11.46 \pm 0.17$ & $10.94 \pm 0.36$ & $11.68 \pm 0.27$ & $11.41 \pm 0.22$ & NS \\
\hline WBCs $\left(\times 10^{3} / \mathrm{mm}^{3}\right)$ & $9.75^{c} \pm 0.06$ & $10.14^{\mathrm{b}} \pm 0.09$ & $10.64^{a} \pm 0.05$ & $10.47^{\mathrm{a}} \pm 0.08$ & 0.0001 \\
\hline PCV (\%) & $29.63^{\mathrm{ab}} \pm 0.62$ & $28.73^{\mathrm{b}} \pm 0.16$ & $30.53^{a} \pm 0.23$ & $29.06^{b} \pm 0.60$ & 0.05 \\
\hline
\end{tabular}

${ }^{a-c}$ Means within rows with different superscript letters differ significantly $(P<0.05)$. NS = not significant.

In addition, supplementation of Se-algae at $0.4 \mathrm{mg}$ was the highest $(\mathrm{P}<0.05)$ group in packed cell volume when compared with control and the other treatment groups. The increase in the PCV might be due to the boosting effects of moderate levels of selenium on the immune system which enhance the process of the production of red blood cells in the body while decline in the PCV with increased selenium could probably be due to inhibitory constituents of the fed which was not determined in this case.

\section{Blood constituents}

The effects of dietary Se-algae supplementation levels on blood constituents of Barki ram-lambs are presented in Table (3). Results of the present study demonstrated that dietary Se-algae supplementation caused significant increases in plasma total protein and albumin when compared with the control group. Plasma albumin of the ram-lambs on $0.6 \mathrm{mg}$ Se-algae supplementation was significantly $(p<0.0001)$ higher than those of lambs on 0.2 Se-algae diets. On the other hand, animals fed on diet supplemented with Sealgae at $0.6 \mathrm{mg}$ recoded the lowest $(\mathrm{P}<0.05)$ value of plasma globulin $(3.02$ $\mathrm{g} / \mathrm{dl})$. McConnell and Hoffman (1972) attributed these increases in total protein and albumin to the fact that seleno-methionine was incorporated into liver polypeptides via the methionine pathway. Selenium is present in two biologically active forms, Se containing enzymes and Se-containing proteins in animals (Zhang et al., 2011). The control group (without supplementation of Se-algae) showed the lowest total protein and albumin, this reduction might be due to oxidative damage in proteins ranges from specific amino acid modifications and peptide breakage to loss of enzyme activity (Stadtman and Levine, 2003). Little information on the selenium form in Se-enriched Spirulina is available for the present time. Selenium is assumed to be built into the protein structure similar to that into Se-enriched yeast (Machat et al., 2005), so Se-enriched spirulina may be used as a potential form of organic selenium supplemented to sows diets (Kotrbaček et al., 2004). 
The results of Table (3) revealed that plasma concentrations of glucose, creatinine, triglycerides and enzyme alanine aminotransferase (ALT) were not affected significantly by dietary supplementation with different levels of Se algae.Data in Table (3) indicated that dietary Se-algae supplementation significantly reduced plasma cholesterol and total lipid contents compared with the control group. Ram-lambs fed diets supplemented with 0.2 and $0.4 \mathrm{mg} \mathrm{Se}$ algae had the lowest values of cholesterol content $(78.37$ and $77.72 \mathrm{mg} / \mathrm{dl}$, respectively). This may be attributed to the anabolic role of Se on fat deposition. The effects of this supplementation were to modulate fatty acid composition in the whole body. These alterations could be also due to the Spirulina components such as polyunsaturated fatty acids, phycocyanin which are thought to be compounds with antioxidant abilities according to Nagaoka et al. (2005). Similarly, Ebied et al. (2012) noted that rabbits fed diets supplemented with 0.15 or 0.3 ppm organic Se significantly reduced total lipid compared with the control groups.

Ram-lambs on $0.4 \mathrm{mg}$ Se-algae diet had plasma ALT level less than that of the groups on $0.2 \mathrm{mg}$ and $0.6 \mathrm{mg}$ Se-algae or control group, with insignificant differences ( $p>0.05$ ) between them. However, plasma AST level of the ram-lambs fed diet containing $0.4 \mathrm{mg}$ Se-algae was significantly $(p<0.05)$ higher when compared to those of other groups. In addition, plasma ALP of the control group was significantly $(p<0.0001)$ higher as compared to those of groups fed diets supplemented with different levels of Se-algae. Abood et al. (2012) reported that Awassi ewes and their newborn lambs suffering from

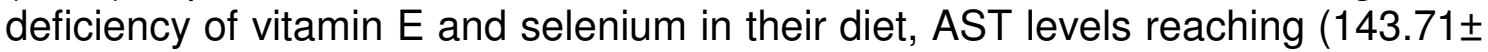
$4.28 \mathrm{U} / \mathrm{L})$ and $(145.40 \pm 7.94 \mathrm{U} / \mathrm{L})$ in deficient groups of ewes and lambs, respectively compared with non-deficiency groups in which levels reached $(69.14 \pm 2.78 \mathrm{U} / \mathrm{L})$ and $(72.85 \pm 2.33 \mathrm{U} / \mathrm{L})$ respectively.

Table (3). The effect of different levels of dietary Se-algae supplementation on blood constituents of the experimental ram-lambs $(n=7)$. (MeanıSE)

\begin{tabular}{|c|c|c|c|c|c|}
\hline \multirow{2}{*}{ Parameters } & \multicolumn{4}{|c|}{ Se-algae supplementation (mg/kg DM) } & \multirow{2}{*}{ P-value } \\
\hline & Control & 0.2 & 0.4 & 0.6 & \\
\hline Total protein (g/dl) & $6.43^{b} \pm 0.03$ & $6.61^{\mathrm{a}} \pm 0.05$ & $6.71^{\mathrm{a}} \pm 0.05$ & $6.65^{\mathrm{a}} \pm 0.05$ & 0.001 \\
\hline Albumin (g/dl) & $3.23^{\mathrm{c}} \pm 0.06$ & $3.46^{\mathrm{b}} \pm 0.03$ & $3.55^{\mathrm{ab}} \pm 0.02$ & $3.63^{\mathrm{a}} \pm 0.03$ & 0.0001 \\
\hline Globulin (q/dl) & $3.20^{a} \pm 0.07$ & $3.15^{\mathrm{a}} \pm 0.02$ & $3.16^{a} \pm 0.02$ & $3.02^{b} \pm 0.02$ & 0.04 \\
\hline Glucose (mg / dl) & $59.22 \pm 1.23$ & $57.91 \pm 1.19$ & $61.02 \pm 1.00$ & $59.14 \pm 1.32$ & NS \\
\hline Urea -N (mg/dl) & $57.80^{\mathrm{b}} \pm 1.13$ & $60.57^{\mathrm{ab}} \pm 0.63$ & $63.16^{\mathrm{a}} \pm 1.20$ & $60.13^{\mathrm{b}} \pm 0.80$ & 0.0085 \\
\hline Creatinine $(\mathrm{mg} / \mathrm{dl})$ & $1.05 \pm 0.01$ & $1.02 \pm 0.02$ & $1.02 \pm 0.02$ & $1.01 \pm 0.02$ & NS \\
\hline Total Lipids (mg/dl) & $990^{a} \pm 0.008$ & $904^{b} \pm 0.005$ & $900^{\mathrm{b}} \pm 0.004$ & $909^{b} \pm 0.009$ & 0.0001 \\
\hline Cholesterol (mg/dl) & $82.45^{\mathrm{a}} \pm 1.54$ & $78.37^{\mathrm{b}} \pm 0.66$ & $77.72^{\mathrm{b}} \pm 1.74$ & $81.01^{\mathrm{ab}} \pm 0.62$ & 0.046 \\
\hline Triglycerides (mg/dl) & $42.70 \pm 0.27$ & $39.26 \pm 0.24$ & $41.91 \pm 2.23$ & $39.60 \pm 0.45$ & NS \\
\hline AST (u/l) & $55.13^{\mathrm{b}} \pm 1.17$ & $57.74^{\mathrm{b}} \pm 1.30$ & $61.69^{\mathrm{a}} \pm 0.94$ & $55.20^{\mathrm{b}} \pm 1.69$ & 0.03 \\
\hline ALT $(u / I)$ & $47.55 \pm 2.15$ & $47.87 \pm 1.36$ & $43.86 \pm 1.54$ & $46.86 \pm 2.55$ & NS \\
\hline $\operatorname{ALP}(u / l)$ & $571.23^{\mathrm{a}} \pm 10.03$ & $452.25^{\mathrm{b}} \pm 10.48$ & $391.85^{c} \pm 9.24$ & $359.14^{d} \pm 3.41$ & 0.0001 \\
\hline
\end{tabular}




\section{Animal's antioxidative status}

Data on the effect of dietary inclusion of Se-algae at different levels on antioxidantive status of Barki ram-lambs are presented in Table (4). Dietary Sealgae supplementation resulted in significant effects on plasma blood antioxidative properties as measured by T-AOC and MDA as an index of oxidation and antioxidant enzymes such as GSH-Px and SOD. There were gradual and significant increases in T-AOC, GSH-Px and SOD as Se-algae level increased. Ram-lambs fed diet supplemented with $0.6 \mathrm{mg}$ Se-algae recorded the highest levels of T-AOC., GSH-Px and SOD as compared with other levels of Se-algae supplementation. These results are in agreement with those of Cao et al. (2014) who found that the T-AOC of serum from pig fed on $0.3 \mathrm{mg} / \mathrm{kg}$ DL-Se Met supplemented diet was significantly higher compared with the low-Se and $0.3 \mathrm{mg} / \mathrm{kg}$ sodium selenite groups $(\mathrm{P}<0.05)$.

Yue et al. (2009) found that serum SOD activity was higher $(p<0.05)$ in goats supplemented with both 0.30 and $0.50 \mathrm{mg} \mathrm{Se} / \mathrm{kg}$ DM than in control goats and goats supplemented with high level of selenium $1.00 \mathrm{mg} \mathrm{Se} / \mathrm{kg}$ DM. In accordance with our results, Faixova et al. (2007) found that lambs fed diet supplemented with $0.3 \mathrm{mg} \cdot \mathrm{kg}^{-1} \mathrm{DM}$ in the form of Se-enriched yeast and giving a total daily intake $278 \mu \mathrm{g}$ of Se per animal.recorded the highest GSH-Px (830.85 $\pm 69.23 \mathrm{U} / \mathrm{g} \mathrm{Hb}$ ) when compared with the control group (that received a basic diet providing a daily intake $50.6 \mu \mathrm{g}$ of Se only). A high and linear parallel between the Se concentration and GPx activity of blood has been reported by several authors (Pavlata et al. 2001; Rock et al., 2001). Our results prove the positive correlation between blood Se content and the activity of this selenoenzyme. Opposite results were reported by Svoboda et al. (2009) who found that GSH-Px activities of the whole blood in both sows and piglets did not differ between groups fed on diet supplemented with inorganic Se (sodium selenite, $0.3 \mathrm{mg} / \mathrm{kg}$ ) and those fed on diet supplemented with organic Se from Se-enriched alga (0.3 mg/kg). Also, Mahan and Peters (2004) and Yoon and McMillan (2006) found that both Se from Se-enriched yeast and inorganic form are adequate for the synthesis of GSH-Px.

Results shown in Table (4) also indicated that dietary Se-algae supplementation significantly $(\mathrm{P}<0.0001)$ reduced MDA compared with the control, and this reduction was dose-dependent reaching $31.1 \%$ as compared with the control group at $0.6 \mathrm{mg} \mathrm{Se}$-algae. MDA is one of the final products of polyunsaturated fatty acid peroxidation in cells and is considered as a marker of oxidative stress (Gawel et al., 2004). Zhan et al. (2007) reported that supplementing $0.3 \mathrm{mg} / \mathrm{kg}$ of Se to the diet of finishing pig significantly decreased the content of MDA both in liver and muscle. However, the content of tissue MDA in selenomethionine-treated group was slightly lower than that in sodium selenite group, especially in muscle (Wang et al., 2011). Increased GSH-Px and decreased MDA are good indicators of improved oxidative defense of animal tissues (Celli, 2010). 
Table (4). The effect of different levels of dietary Se-algae supplementation on antioxidative status of the experimental ram-lambs $(n=7)$. (Mean \pm SE)

\begin{tabular}{lccccc}
\hline \multirow{2}{*}{ Parameters } & \multicolumn{4}{c}{ Se-algae supplementation (mg/kg DM) } & \multirow{2}{*}{ P- value } \\
\cline { 2 - 6 } & Control & $\mathbf{0 . 2}$ & $\mathbf{0 . 4}$ & $\mathbf{0 . 6}$ & \\
\hline MDA (mmol/l) & $14.65^{\mathrm{a}} \pm 0.56$ & $13.40^{\mathrm{b}} \pm 0.28$ & $12.26^{\mathrm{c}} \pm 0.30$ & $10.10^{\mathrm{d}} \pm 0.13$ & 0.0001 \\
T-AOC (mmol/l) & $133.92^{\mathrm{d}} \pm 1.59$ & $144.85^{\mathrm{c}} \pm 1.23$ & $150.21^{\mathrm{b}} \pm 1.55$ & $159.64^{\mathrm{a}} \pm 0.34$ & 0.0001 \\
SOD (u/l) & $24.83^{\mathrm{b}} \pm 0.6$ & $30.22^{\mathrm{a}} \pm 0.30$ & $32.91^{\mathrm{a}} \pm 0.80$ & $35.71^{\mathrm{a}} \pm 0.50$ & 0.0001 \\
GSH-Px (u/l) & $456.04^{\mathrm{d}} \pm 7.24$ & $530.42^{\mathrm{c}} \pm 6.37$ & $563.02^{\mathrm{b}} \pm 11.01$ & $650.52^{\mathrm{a}} \pm 14.30$ & 0.0001 \\
\hline a-d Means within rows with different superscript letters differ significantly $(\mathrm{P}<0.01)$. & \\
NS = not significant. \\
MDA=Malondialdehyde, T-AOC=Total antioxidant capacity, SOD=Superoxide dismutase and \\
GSH-Px = Glutathione peroxidase.
\end{tabular}

\section{Semen characteristics}

The influence of addition different levels of Se-algae to the diet of lambs on their semen traits are presented in Table (5). Results showed that ejaculate volume of Barki rams increased as a result of supplementing their diets with se-algae. This increase $(p<0.01)$ reached $7.45 \%$ for animals receiving diet containing 0.6 Se-algae compared to the control group, while the increases were insignificant and amounted 3.33 and $4.40 \%$ for animals fed diets supplemented with 0.2 and $0.4 \mathrm{mg}$ Se-algae, respectively. Semen volume is an important factor in semen evaluation and reproductive performance in males (Ax et al., 2000). Hashem (2014) showed that the average volume of semen was 1.03 $0.001 \mathrm{ml}$ in Siwa Barki sheep during a 12-month period (four seasons).

Hydrogen ion concentration $(\mathrm{pH})$ was not affected significantly by adding different levels of Se-algae to the diet. However, semen hydrogen ion concentration showed numerical decrease due to inclusion of Se-algae in the diets as compared to the control group. This decrease in $\mathrm{pH}$ of the selenium supplemented group may be due to the decrease in percentage of dead sperm.

The highest values of Sperm progressive motility were recorded in the group receiving $0.6 \mathrm{mg}$ Se-algae containing diet. Selenium supplementation improved $(p<0.0001)$ motility of ram semen. Sperm motility is a fairly reliable indication of the viability of fresh semen (Grahman et al., 1980). The motile spermatozoa provide strong evidence for sperm maturation. Ali et al. (2009) found that treating Awassi rams for 90 days twice weekly with $175 \mathrm{mg} / \mathrm{ram}$ vitamin $\mathrm{E}$ and 70 $\mathrm{mg} / \mathrm{ram}$ vitamin E plus $2800 \mathrm{mg}$ selenium caused individual motility to increase compared with untreated group.

Sperm concentration in semen of Barki ram-lambs showed significant $(P \leq 0.05)$ decrease in treated groups comparing with the control group. The lowest values of sperm concentration were recorded in the group receiving $0.4 \%$ Se-algae containing diet. In this respect, 
selenium supplementation was reported to significantly decrease the sperm concentration in semen of boars supplemented by 0.3 and $0.6 \mathrm{mg}$ $\mathrm{Se} / \mathrm{kg}$ of feed mixture in inorganic form (Hork 2012). Hashem (2014) showed that average sperm concentration was $347 \times 10^{9} \mathrm{ml}$ in Siwa Barki sheep. Hafez and Hafez (2000) reported that the sperm concentration of an ejaculate ranges from 3.5 to $6.0 \times 10^{9} \mathrm{ml}$ in ram. Opposite to aim results was conducted by Ali et al. (2009) reported that after 3 months of treating Awassi rams with $175 \mathrm{mg} / \mathrm{ram}$ vitamin $\mathrm{E}$ and $70 \mathrm{mg} / \mathrm{ram}$ vitamin E plus $2800 \mathrm{mg}$ selenium, the Sperm concentration was increased compared with untreated group.

Normal sperm and live sperm showed significant $(P \leq 0.05)$ increases in treated groups comparing with the control group. The highest values of normal sperm was recorded in the group receiving $0.6 \mathrm{mg} \%$ Se-algae containing diet, but the highest values of live sperm was recorded in the group receiving 0.4 and $0.6 \mathrm{mg}$ Se-algae containing diet. Beneficial effects of supplementary trace minerals ( $\mathrm{Zn}$, Co and Se) (Kendall et al., 2000) and selenium (Anderson et al., 1996) on percentages of live sperm in ram lambs have been reported. Abnormal sperm and dead sperm showed opposite trends. The best values of abnormal sperm and dead sperm was recorded in the group receiving $0.6 \mathrm{mg} \%$ Se-algae containing diet. These results agree with these of Ali et al. (2009). The present data showed that inclusion of Sealgae in the ram-lambs diets significantly $(P \leq 0.05)$ increased total sperm output and total motile sperm. Results also showed that TFSF was significantly ( $P \leq 0.0002)$ increased by different levels of Se-algae. The best values for total sperm output, total motile sperm and TFSF were recorded in the groups of ram-lambs fed diet containing $0.6 \mathrm{mg}$ Se-algae as compared to the control or the other experimental groups.

Table (5). Means \pm SE of semen traits of mature Barki rams fed diets supplemented with different levels of Se-algae $(n=7)$

\begin{tabular}{|c|c|c|c|c|c|}
\hline \multirow{2}{*}{ Parameters } & \multicolumn{4}{|c|}{ Se-algae supplementation (mg/kg DM) } & \multirow{2}{*}{$\begin{array}{c}\text { P. } \\
\text { value }\end{array}$} \\
\hline & Control & 0.2 & 0.4 & 0.6 & \\
\hline Ejaculate volume(ml) & $0.87 b \pm 0.02$ & $0.90 a b \pm 0.02$ & $0.91 a b \pm 0.02$ & $0.94 a \pm 0.02$ & 0.01 \\
\hline Semen pH & $6.69 \pm 0.02$ & $6.51 \pm 0.03$ & $6.51 \pm 0.02$ & $6.50 \pm 0.02$ & NS \\
\hline Progressive motility (\%) & $67.90 \mathrm{~b} \pm 0.84$ & $77.90 \mathrm{a} \pm 1.42$ & $82.80 \mathrm{a} \pm 1.78$ & $83.10 a \pm 2.65$ & 0.0001 \\
\hline Sperm concentration $(x 107 / \mathrm{ml})$ & $312.70 \mathrm{a} \pm 8.02$ & $285.30 \mathrm{~b} \pm 3.84$ & $282.40 \mathrm{~b} \pm 2.87$ & $293.30 b \pm 4.54$ & 0.05 \\
\hline Normal sperm (\%) & $77.06 b \pm 0.66$ & $78.83 b \pm 0.74$ & $79.13 b \pm 0.37$ & $81.31 \mathrm{a} \pm 0.57$ & 0.003 \\
\hline Abnormal sperm (\%) & $22.94 a \pm 0.66$ & $21.17 b \pm 0.74$ & $20.88 b \pm 0.37$ & $18.69 c \pm 0.57$ & 0.0005 \\
\hline Live sperm (\%) & $79.66 c \pm 0.74$ & $83.00 b \pm 2.44$ & $85.33 a \pm 3.40$ & $86.50 a \pm 0.76$ & 0.0001 \\
\hline Dead sperm (\%) & $20.83 a \pm 2.76$ & $17.00 \mathrm{~b} \pm 2.47$ & $14.83 c \pm 3.33$ & $13.83 c \pm 2.78$ & 0.0001 \\
\hline Sperm output(x107/ ejaculate) & $288.09 a b \pm 6.79$ & $271.80 \mathrm{~b} \pm 7.03$ & $270.96 b \pm 7.99$ & $294.36 a \pm 7.48$ & 0.05 \\
\hline Motile sperm(x107/ ejaculate) & $195.01 c \pm 4.32$ & $213.07 b c \pm 3.77$ & $229.94 a b \pm 10.37$ & $250.45 a \pm 13.07$ & 0.0018 \\
\hline TFSF (x107/ejaculate) & $151 c \pm 3.24$ & $170 \mathrm{bc} \pm 8.64$ & $185 a b \pm 12.05$ & $206 a \pm 13.61$ & 0.0002 \\
\hline
\end{tabular}

\section{Effect of dietary addition different levels of Se-algae on seminal plasma constituents}

Data on the influence of feeding Barki ram-lambs on diets supplemented with different levels of Se- algae on seminal plasma constituents are presented in Table (6). Results showed that seminal plasma total protein, albumin and globulin are significantly $(P \leq 0.05)$ affected by dietary addition of different levels 
of Se-algae as compared to the control group. Seminal plasma total protein showed significant increase in the groups given 0.4 and $0.6 \mathrm{mg}$ Se-algae diets as compared to the control group. Seminal plasma albumin showed insignificant increase in the groups receiving 0.4 and $0.6 \mathrm{mg}$ Se-algae diet as compared to the control group. On the other hand, seminal plasma globulin showed significant decrease in the group receiving $0.4 \mathrm{mg}$ Se-algae diet as compared to the control group.

Concentration of total lipids in semen plasma significantly decreased with inclusion of Se-algae in the diets and these decreases reached 7.15, 6.25 and $9.69 \%$ for diets containing Se-algae at levels of $0.2,0.4$ and 0.6 respectively, as compare to control group. However, seminal plasma cholesterol and triglycerides were not significantly affected by the inclusion of Se-algae in the diets.

Seminal plasma analysis presented in Table (6) showed significant $(P \leq$ 0.01) decreases in concentrations of ALP and ALT as a result of dietary inclusion of Se-algae when compared with the control group. The decline in transaminase enzyme in supplemented groups may be due to the presence of Se ions (Underwood et al., 1977) which may had a protective action to reduce the damage of cell membrane of sperms and sperm dead count which leads to a decline in the release of transaminase enzyme in seminal plasma.

Transaminase enzyme levels of whole semen showed significantly higher activity during stress. These enzymes may rise as a result of the destruction of spermatozoa due to stress factors and the high levels of transaminase enzymes are used as indicator of the degree of membrane damage of spermatozoa (Corteel, 1980). Moreover, Se-algae treatments resulted in a decrease in seminal plasma alkaline phosphates which may play a role in enhancing semen properties as high seminal alkaline phosphates activity in the buffalo was associated with lower sperm numbers, decreased motility and percent of live cells, depressed dehydrogenase activity and a slight and nonsignificant decrease in fructolytic rate (Abdou et al., 1978). The improvement in biochemical constituent's concentration of seminal plasma of ram-lambs on Sealgae supplementation found herein generally are in agreement with those reported by Kamel (2012) who found that administration of selenium and folic acid or their combination increased $(\mathrm{P}<0.05)$ seminal plasma total proteins, globulins, alkaline phosphatase, acid phosphatase and lactate dehydrogenase.

Conversely, seminal plasma aspartate aminotransferase, alanine aminotransferase were significantly decreased compared to the control group. Although, initial fructose was non-significantly affected by different treatments, the results showed numerical increase in initial fructose in the groups fed all levels of Se-algae diets. The numerical increases of initial fructose were 2.1, 3.8 and $8.9 \%$ for $0.2,0.4$ and $0.6 \mathrm{mg}$ Se-algae fed groups, respectively. 
Table (6). Means $\pm S E$ of semen constituents of Barki mature rams fed diets supplemented with different levels of Se-Algae $(n=7)$

\begin{tabular}{|c|c|c|c|c|c|}
\hline \multirow{2}{*}{ Parameters } & \multicolumn{4}{|c|}{ Se-algae supplementation (mg/kg DM) } & \multirow{2}{*}{$\begin{array}{c}\text { P- } \\
\text { value }\end{array}$} \\
\hline & Control & 0.2 & 0.4 & 0.6 & \\
\hline Total protein $(\mathrm{g} / \mathrm{dl})$ & $6.10^{b} \pm 0.09$ & $6.22^{\mathrm{ab}} \pm 0.12$ & $6.38^{\mathrm{a}} \pm 0.13$ & $6.33^{\mathrm{a}} \pm 0.11$ & 0.0192 \\
\hline Albumin $(\mathrm{g} / \mathrm{dl})$ & $3.09^{c} \pm 0.04$ & $3.16^{\mathrm{c}} \pm 0.06$ & $3.57^{\mathrm{a}} \pm 0.07$ & $3.37^{b} \pm 0.06$ & 0.0001 \\
\hline Globulin (g/dl) & $3.01^{a} \pm 0.12$ & $3.04^{\mathrm{a}} \pm 0.06$ & $2.82^{b} \pm 0.06$ & $2.96^{\mathrm{ab}} \pm 0.05$ & 0.05 \\
\hline Total lipids (mg/dl) & $908^{\mathrm{a}} \pm 0.005$ & $843^{b} \pm 0.011$ & $851^{\mathrm{b}} \pm 0.011$ & $820^{b} \pm 0.024$ & 0.0288 \\
\hline Triglycerides (mg/dl) & $238.10 \pm 4.50$ & $225.70 \pm 9.19$ & $221.60 \pm 11.02$ & $220.00 \pm 17.05$ & NS \\
\hline Cholesterol (mg/dl) & $213.60 \pm 3.49$ & $204.80 \pm 10.67$ & $201.70 \pm 11.71$ & $200.60 \pm 9.35$ & NS \\
\hline $\operatorname{ALT}(u / l)$ & $65.09^{\mathrm{a}} \pm 1.39$ & $60.74^{b} \pm 3.83$ & $60.15^{\mathrm{b}} \pm 4.55$ & $61.55^{\mathrm{b}} \pm 3.14$ & 0.05 \\
\hline AST (u/l) & $84.62 \pm 0.61$ & $86.75 \pm 2.03$ & $86.86 \pm 2.06$ & $87.25 \pm 1.63$ & NS \\
\hline ALP $(u / l)$ & $17.48^{\mathrm{a}} \pm 0.08$ & $15.80^{\mathrm{b}} \pm 0.43$ & $13.63^{c} \pm 0.25$ & $12.70^{d} \pm 0.37$ & 0.0001 \\
\hline Initial fructose (mg/dl) & $269.40 \pm 0.21$ & $275.16 \pm 0.24$ & $280.01 \pm 0.23$ & $295.60 \pm 0.26$ & NS \\
\hline
\end{tabular}

In conclusion, results of the present study demonstrated that supplemented diets of Barki ram-lambs with different levels of Se-algae increased final body weight and weight gain also; it improved their anti-oxidative status and semen quality.

\section{REFERENCES}

Abdou, M. S. S., M. M. El-Guindi, A. A. El-Menoufy and K. Zaki (1978). Enzymic Profile of the Semen of Bovines (Bubalus bubalis and Bos taurus). Zentralblatt für Veterinärmedizin Reihe A. 25, 222-230. doi: 10.1111/j.1439-0442.1978.tb00922.x.

Abood, H. K., A. M. H. Judi and A. A. AL-Ani (2012). The effect of experimentally induced vitamin $\mathrm{E}$ and selenium deficiency on Creatine Kinase (CK) and Aspartate Aminotransferase (AST) activities in Awassi ewes and their newborn lambs. Kufa J. Vet. Med. Sci., 3: 132-137.

Ali, A. T., G. Bomboi and B. Floris (2009). Does Vitamin E or Vitamin E plus Selenium improve reproductive performance of rams during hot weather. Ital. J. Anim. Sci., 8: 743-754.

Aller, J. F., D. Aguilar, T. Vera, G. P. Almeida and R. H. Alberio (2012). Seasonal variation in sexual behavior, plasma testosterone and semen characteristics of Argentine Pampinta and Corriedale rams. Span. J. Agric. Res., 10: 345-352.

Al-Waeli A., E. Zoidis, A. C. Pappas, N. Demiris, G. Zervas and K. Fegeros (2013). The role of organic selenium in cadmium toxicity: effects on broiler performance and health status. J. Anim. Sci., 7: 386-393.

Anderson, J. M. L., Apdewi I. and R. F. E. Axford (1996). The effect of selenium supplementation on fresh and frozen ram semen. J. Anim. Sci., 62: 672 .

Ax, RL, M.R. Dally, B. A. Didon, R. W. Lenz, C. C. Love, D.D. Varner, B. Hafez and M. E. Bellin (2000). Artificial Insemination. In: Hafez, B. Hafez, E.S.E. (Eds.): Reproduction in Farm Animals. (7th Eds.) Philadelphia, Lea and Febinger, 376-389. 
Blache, D., S. K. Maloney and D. K. Revell (2008). Use and limitations of alternative feed resources to sustain and improve reproductive performance in sheep and goats. Anim. Feed Sci. and Techlo., 147: 140157.

Blom, E. (1950). A one-minute live-dead sperm stain by means of eosinnigrosin. J. Fertil. Steril., 1: 176-7.

Cao, J., F. Guo, L. Zhang, B. Dong and L. Gong (2014). Effects of dietary Selenomethionine supplementation on growth performance, antioxidant status, plasma selenium concentration, and immune function in weaning pigs. J. Anim. Sci. and Biotechnology, 5: 46.

Celli, P. (2010). The role of oxidative stress in small ruminants' health and production. Rev. Bras. Zootec, 39: 348-363

Cheong, F. H., F. Y. Kim, D. Sok, S. Hwang, J. H. Kim, H. Kim, J. H. Lee, Y. Kim and M. Kim (2010). Spirulina prevents atherosclerosis by reducing hypercholesterolemia in rabbits fed a high-cholesterol diet. J. Nutr. Sci. Vitaminology, 56: 34-40.

Correa, J. R. and P. M. Zavos (1996). Preparation and recovery of frozen thawed bovine spermatozoa via various sperm selection techniques employed in assisted reproductive technologies. Theriogenology, 46: 1225-1232.

Corteel, J. M. (1980). Effets du plasma séminal sur la survie et la fertilité des sper matozoids conservés in vitro. Reprod. Nutr. Dévelop., 20: 11111123.

Ebeid, T., H. Zeweil, M. Basyouny and H. Badry (2012). The impact of incorporation of organic selenium into meat on growth performance, antioxidative status, and immune response in growing rabbits. Proceedings of the $10^{\text {th }}$ World Rabbit Congress, Sharm El-Sheikh, Egypt, 861-864.

Duncan, D. B. (1955). Multiple range and multiple F-test. Biometrics, 11: 1.

Faixova, Z., Faix, A. Leng, P. Vaczi, Z. Makova and R. Szaboova (2007). Haematological, Blood and Rumen Chemistry Changes in Lambs Following Supplementation with Se-yeast. Acta Vet. Brno., 76: 3-8.

Gawel S, M. Wardas, E. Niedworok and P. Wardas (2004). Malondialdehyde (MDA) as a lipid peroxidation marker. Wiad. Lek., 57: 453-455.

Grahman E. F., M. K. L. Schmehl and D. S. Nelson (1980). Problem with laboratory assays. Proceedings of the 8th Technical Conference on Artificial Insemination and Reproduction. NAAB. 1-8.

Griffiths, L. M., S. H. Loeffler, M. T. Socha, D. J. Tomlinson and A. B. Johnson (2007). Effects of supplementing complexed zinc, manganese, copper and cobalt on lactation and reproductive performance of intensively grazed lactating dairy cattle on the South Island of New Zealand. Anim. Feed Sci. and Technolo., 137: 69-83.

Habeeb, A. A., I. F. M. Marai and T. H. Kamal (1992). Heat stress, In Farm Animals and the Environment, edited by C. Philips and D. Piggens. CAB International. pp 27-47.

Hafez, B. and E. S. E. Hafez (2000). Reproduction in Farm Animals. 7th Ed.. Lippincott Williams and Wilkens, New York, pp: 509. 
Hashem, A. L. S. (2014). Semen Physical Traits and Thyroid Activity of Barki Rams as Affected by Season and Feeding Non-Edible Date Palm at Siwa Oasis, Egypt. World Appli Sci. J., 30: 556-566.

Hepler, O. E. (1966). Manual of Clinical Laboratory Methods. Thomas, Sprongfield, Illinois, USA.

Hork P. (2012). The effect of varius forms (organic, inorganic) and levels of selenium on the laboratory values of the ejaculate of breeding boars in summer season. Research in pig breeding, 6: 24-32.

IRRG, International Rabbit Reproduction Group (2005). Guidelines for the handling of rabbit bucks and semen. World Rabbit Sci., 13: 71- 91.

Irvine, D. S. (1996). Glutathione as a treatment for male infertility. Rev. Reprod., 1: 6-12.

Jones, M. L. and R. W. Allison (2007). Evaluation of theruminant complete blood cell count. Vet. Clin. Northam.: Food Anim. Pract., 23: 377-402.

Kamar, G. A. R. (1960). The influence of semen characteristics on hatching results of chicken eggs. Poultry Science, 39: 188-193.

Kamel, K. (2012). The effect of dietary organic selenium and folic acid supplementation on productive and reproductive performance of male rabbits under heat stress conditions. Egypt. Poult. Sci., 32: 43-62.

Kendall, N. R., S. McMullen, A. Green, and R. G. Rodway (2000). The effect of zinc, cobalt and selenium soluble glass bolus on trace element status and semen quality of ram lambs. Anim. Reprod. Sci., 62: 277-283.

Kim, Y. Y. and D. C. Mahan (2001). rolonged feeding of high dietary levels of organic and inorganic selenium to gilts from $25 \mathrm{~kg}$ body weight through one parity. J. of Anim. Sci., 79: 956-966.

Kotrbáček, V., J. Doucha and T. Offenbartl (2004). Use of Chlorella as a carrier of organic-bound iodine in the nutrition of sows. Czech J. Anim. Sci., 49: 28-32.

Machat, J., J. Čmelík, J. Doucha and V. Otruba (2005). Selenium obohacené rasy Chlorella - frakcionace forem selenu. In: Mikroelementy 2005. 2THETA, Český Těšín, 71-75.

Madibela, O. R., B. M. Mosimanyana, W. S. Boitumelo and T. D. Pelaelo (2002). Effect of supplementation on reproduction of wet season kidding Tswana goats. South African J. Anim. Sci., 32: 14-22.

Mahan, D. C. and N. A. Parrett (1996). Evaluating the efficacy of Se enriched yeast and inorganic selenite on tissue retention and serum glutathione peroxidase activity in grower finisher swine. J. Anim. Sci., 74: 2967-2974.

Mahan, D. C. (1999). Organic selenium: using nature's model to redefine selenium supplementation for animals. In Biotechnology in the feed industry (ed. TP Lyons and KA Jacques), Nottingham University Press, Nottingham, UK. pp. 523-535.

Mahan, D. C. and J. C. Peters (2004). Long-term effects dietary organic and inorganic selenium sources and levels on reproducing sows and their progeny. J. Anim. Sci., 82: 1343-1358.

Mahmoud, K. Z. and F. W. Edens ( 2003). Influence of selenium sources on age related and mild heat stress-related changes of blood and liver glutathione redox cycle in broiler chickens (Gallus domesticus). Comparative Biochemi. and Physiol., 136: 921-934. 
Mann, T. (1948). Fructose content fructolysis in semen. Practical application in evaluation of semen quality. J. of Agric. Sci., 38: 323-331.

Marai, I. F. M. (1987). Intensification of Sheep Production (In Arabic). Zagazig University Press, Zagazig, Egypt.

Matanović, K., K. Severin, F. Martinkovic, M. Šimpraga, Z. Janicki, and J. Barišic (2007). Hematological and biochemical changes in organically farmed sheep naturally infected with Fasciola hepatica. J. Parasitol. Res., 101: 1657-1661.

McConnell, K. P. and J. L. Hoffman (1972). Methionine-selenomethionine parallels in rat liver polypeptide chain synthesis. Fed. Proc., 31: 691.

Nagaoka, S., K. Shimizu, H. Kaneko, F. Shibayama, K. Morikawa, Y. Kanamaru, A. Otsuka, T. Hirahashi and T. Kato (2005). A novel protein C-phycocyanin plays a crucial role in the hypocholesterolemic action of Spirulina platensis concentrate in rats. J. Nutr., 135: 24252430.

Naziroglu, M., M. Aksakal, M. Cay and S. Celik (1997). Effect of vitamin E and selenium on some rumen parameters in lambs. Acta Vet. Hung., 45: 447456.

Pavlata, L., J. Illek and A. Pechová (2001): Blood and tissue selenium concentrations in calves treated with inorganic or organic selenium compounds-a comparison. Acta Vet. Brno., 70: 19-26.

Provan, D., C. R. J. Singer, T. Baglin and J. Lilleyman (2004). Oxford handbook of clinical hematology, 2nd Edition. Oxford University Press, USA.

Rock, M. J., R. L. Kincaid and G. E. Carstens (2001). Effect of prenatal source and level of dietary selenium on passive immunity and thermoregulation of newborn lambs. Small Ruminant Res., 40: 129- 138.

SAS. (2002). SAS User's Guide: Statistical Analysis System Institute, Inc., Cary, NC. USA.

Schrauzer, G. N. (2000). Selenomethionine: a review of its nutritional significance, metabolism and toxicity. J. Nutr., 130: 1653-1656.

Smith, J. T. and D. T. Mayer (1955). Evaluation of sperm concentration by the hemocytometer method. Fertil. Steril., 6: 271-275.

Stadtman, E. R. and E. L. Levine (2003). Free radical-mediated oxidation of free amino acids and amino acid residues in proteins. Amino Acids 25, 207-218.

Svoboda, M., V. Kotrbáček, R. Ficek and J. Drábek (2009). Effect of Organic Selenium from Se-enriched Alga (Chlorella spp.) on Selenium Transfer from Sows to Their Progeny. Acta Vet. Brno., 78: 373-377.

Togun, V. A. and Egbunike G. N. 2006. Seasonal variations in the sperm production characteristics of Zebu (white Fulani) cattle genitalia in the humid tropical environment. Middle-East. J. Sci. Res., 1: 230-244.

Underwood, E. J. 1977. Treace Elements in Human and Animal Nutrition. 3th Ed New York, USA.

Wang, Y. X., X. A. Zhan, D. Yuan, X. W. Zhang and R. J. Wu (2011). Effects of selenomethionine and sodium selenite supplementation on meat quality, selenium distribution and antioxidant status in broilers. Czech J. Anim. Sci., 56: 305-313. 
Yoon, I. and E. McMillan (2006). Comparative effects of organic and inorganic selenium on selenium transfer from sows to nursing pigs. J. of Anim. Sci., 84: 1729-1733.

Yue, W., C. Zhang, L. Shi, Y. Ren, Y. Jiang and D. O. Kleemann (2009). Effect of Supplemental Selenomethio nine on Growth Performance and Serum Antioxidant Status in Taihang Black Goats. Asian-Aust. J. Anim. Sci., 22: 365 - 370.

Zhan, X. A., M. Wang, R. Q. Zhao, WF Li and Z. R. Xu (2007). Effects of different selenium source on selenium distribution, loin quality and antioxidant status in finishing pigs. Anim. Feed Sci. Tech., 132: 202-211. Zhang, Y., S. Zhu, X. Wang, C. Wang and F. Li. (2011). The effect of dietary selenium levels on growth performance, antioxidant capacity and glutathione peroxidase 1 (GSHPx1) mRNA expression in growing meat rabbits. Anim. Feed Sci. and Technolo.,169: 259- 264.

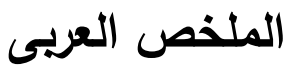

تأثير إضافة الطحالب المجفةة الغتية بالسيلنيوم الى العلائق على الأداء الإنتاجى والتناسلى لذكور أغنام البرقى

هثام الدين غباثى محمد'، محمد حسن أحمد'، عبده جمال الدين عبد ريه '

سليمان محمد زهران"، حسن صابر زويل' 1- معهز بحوث الانتاج الحيوانى - مركز البحوث الزراعية - القاهزة

r- قسم الأنتاج الحيوانى والسمكى - كلية الزراعة (سابا بانشا) - جامعة الاسكندرية

يهدف البحث لدراسة تأثثر إضافة طحالب Spirulina platensis المجفة الغنية بالسيلنيوم الى علائق ذكور أغنام البرقى وذلك على النمو وبعض مكونات الدم وصفات السائل المنوى وايضا بعض إنزيمات الكبد المضادة للاكسدة ـ وقد أستمرت هذه الدراسة لمدة أكثر من عام ونم إجرائها بمحطة بحوث الإنتاج الحيواني ببرج العرب

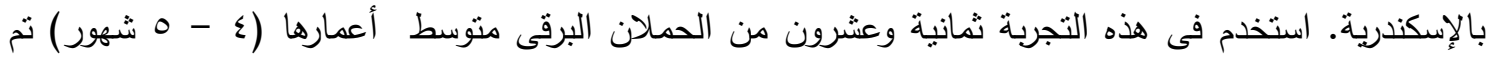

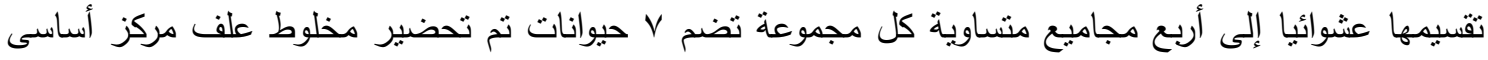

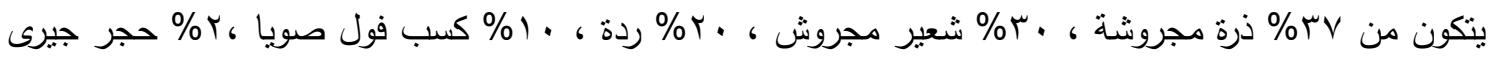

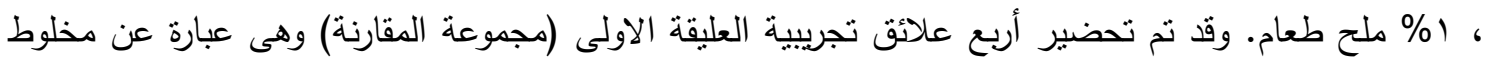

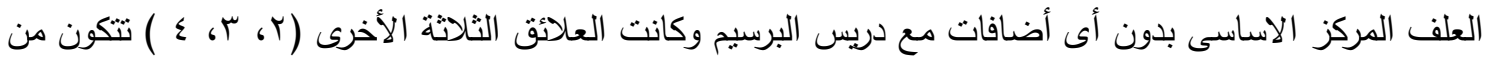

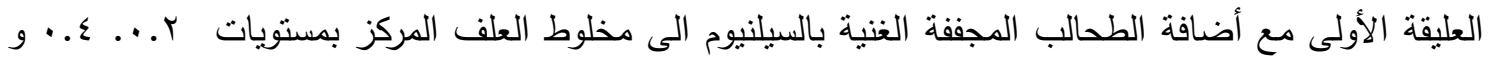
T. . ملجم / كجم علف مركز ، على التوالي.وقد تم تغذية مجاميع الحيوانات الأربعة عشوائيا على العلائق التجريبية الأربعة . 


\section{وكانت أهم النتائج المتحصل عليها كالتالى:-}

1-أظهرت النتائج أن إضافة الطحالب الغنية بالسيلينيوم أدت الى زيادة معنوية فى وزن الجسم ومعدل النمو مقارنة بالمجموعة المقارنة. كما لوحظ أرتفاع معنوى فى عدد كرات الدم البيضاء ومستوى البروتين الكلى وانخفاض

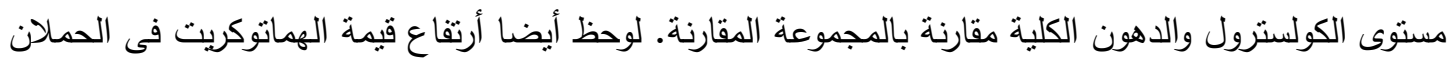

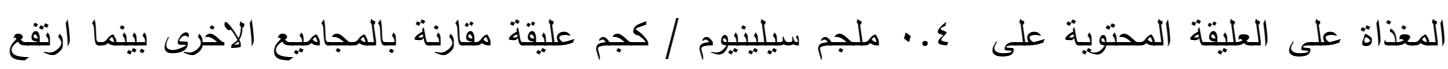
البيومين الدم وانخفض الجلوبيولين عند مستوى 7 .. ـ ملجم / كجم عليقة.

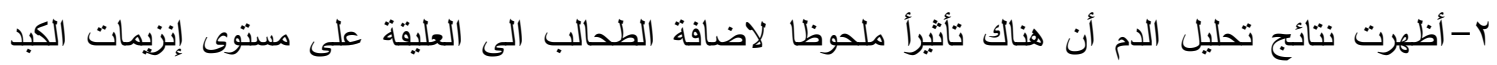
وايضا أنزيم ALP ولو أن هذا التاثير كان فى الحدود الطبيعية المتعارف عليها كما لوحظ حدوث

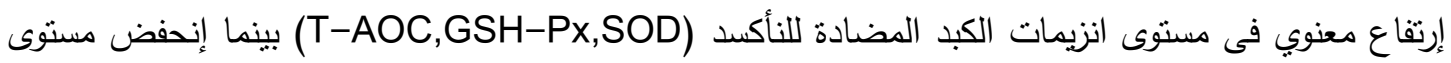
المركب MDA معنويا وذللك عند المقارنة بالمجموعة المقارنة. ץ-أوضحت نتائج تحليل السائل المنوى حدوث زيادة معنوية فى حجم القذفة والعدد الكلى للإسبرمات فى القذفة

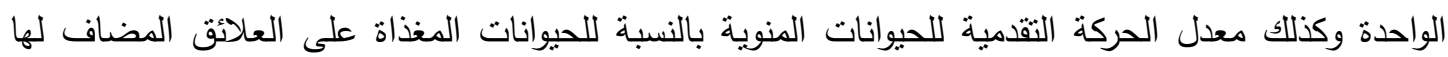
السيلينيوم مقارنة بالمجموعة المقارنة .أيضا لوحظ إرتفاع معنوى فى مسنوى البروتين الكلى فى بلازما السائل

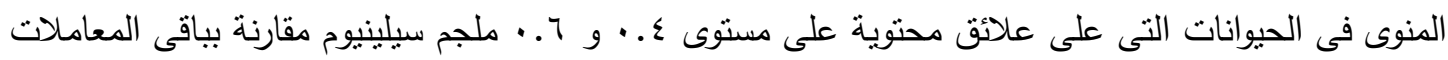
الاخرى.بينما لوحظ إنخفاض معنوى فى مستوى الالبيومين والدهون الكلية وكذلك مستوى ALP, ALT فى الحيوانات المعاملة مقارنة بالمجموعة المقارنة.

من النتائج السابقة نستتتج أنه يمكن أستخدام الطحالب المجفة الغنية بالسيلنيوم فى علائق ذكور الاغنام النامية حيث تؤدى الى زيادة معنوية فى معدلات النمو وتحسين جودة السائل المنوى ومضادات الاكسدة

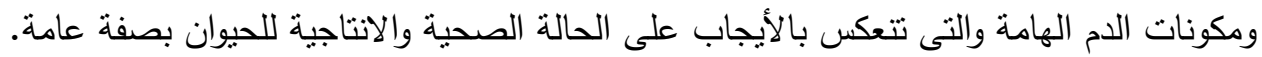


